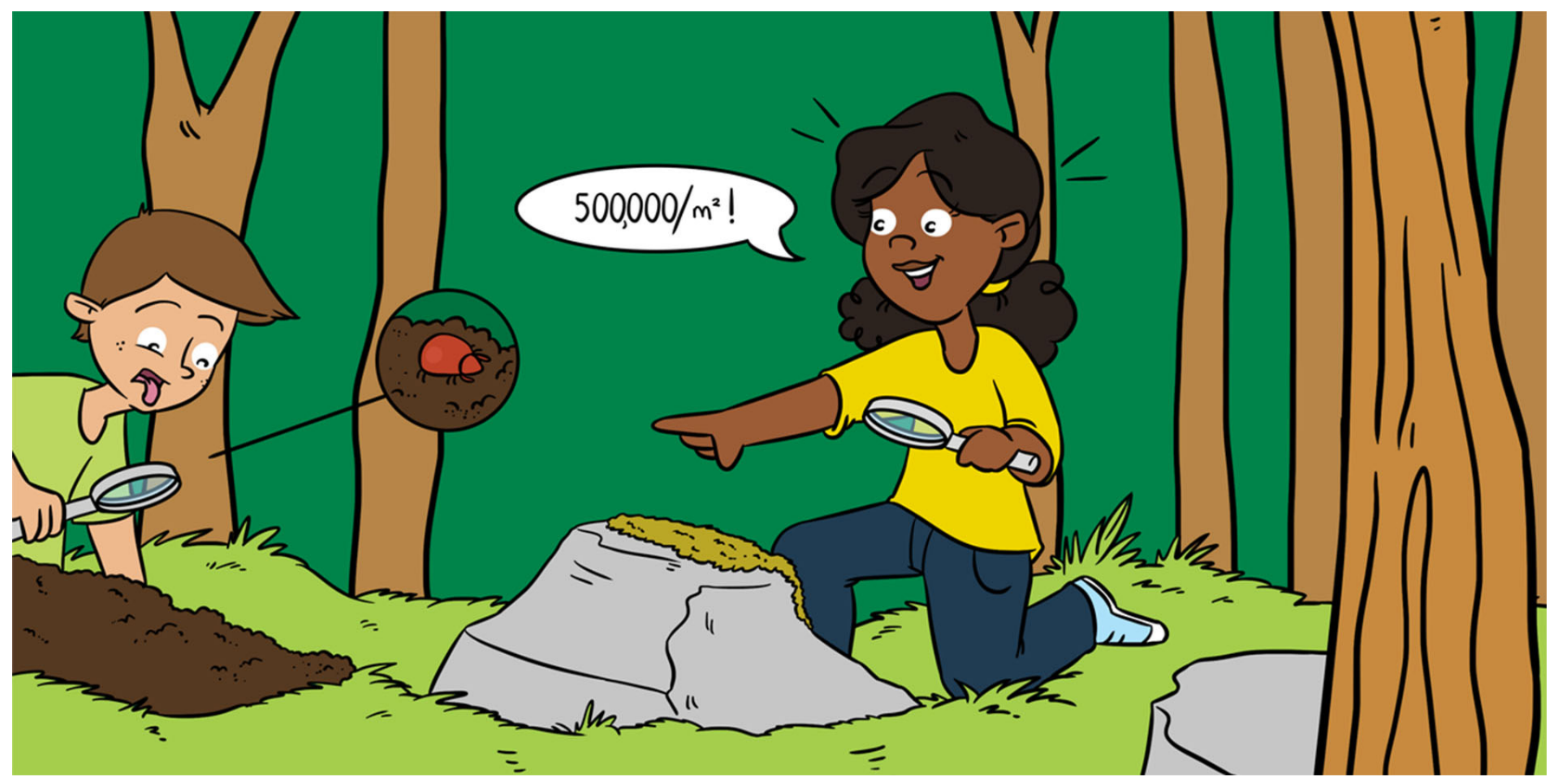

\title{
ARMORED MITES, BEETLE MITES, OR MOSS MITES: THE FANTASTIC WORLD OF ORIBATIDA
}

\section{Carlos Barreto ${ }^{* t}$ and Zoë Lindo ${ }^{+}$}

Soil Biodiversity and Ecosystem Function Laboratory, Department of Biology, Biotron Experimental Climate Change Research Centre, Western University, London, ON, Canada

YOUNG REVIEWERS:

ISABEL

AGE: 10

MARGARIDA

AGE: 12
Oribatid mites are a group of animals related to spiders, scorpions, and ticks. However, they are typically much smaller (most are $<1 \mathrm{~mm}$ ) and are full of defensive mechanisms to protect them from predators. Generally, oribatid mites live in soils and feed on fungi, bacteria, and soil particles, making them very important for decomposition processes. Oribatid mites also help cycle soil nutrients and contribute to soil formation. Oribatid mites can also be found in aquatic environments and even treetops. They are present all over the world, from forests to deserts, and along the edges of lakes and oceans. They are often the most abundant mesofauna found in soils, reaching impressive populations of up to 500,000 individuals per $\mathrm{m}^{2}$ in forests. The diversity of oribatid mites varies across vegetation types, climate, and soil properties, such as moisture, $\mathrm{pH}$, nutrient concentrations, and heavy metals. 
Figure 1

Examples of oribatid mites, with their scientific names

(A) Suctobelbella sp.;

(B) Hoplophorella sp. (also called box mites); (C) defensive hairs on Palaeacarus sp.;

(D) hard body of Diapterobates notatus with an arrow pointing to tooth-like structures to help during feeding;

(E) juvenile Lepidozetes sp.; (F) adult

Lepidozetes sp. (notice that young mites and parents are not alike);

(G) juvenile

Tyrphonothrus sp.; and (H) adult

Tyrphonothrus sp. (notice that young mites and parents are alike).

\section{EXOSKELETON}

The external skeleton that supports and protects an animal's body, in other words, the animals' outer body covering. In can be very hard in oribatid mites.

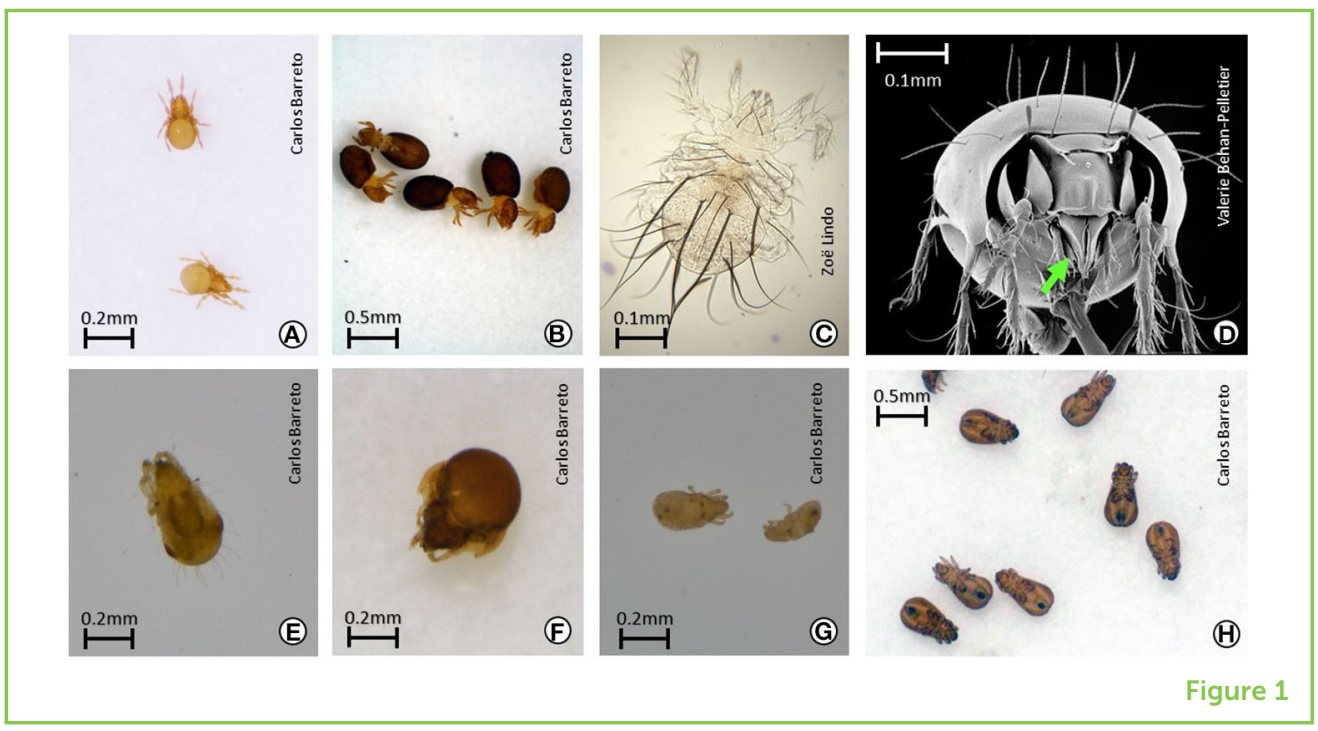

\section{WHO ARE THE ORIBATID MITES?}

Oribatid mites (formal name: Suborder Oribatida) are animals related to spiders, scorpions, and ticks, as they also have eight legs (Figures $1,2)$. While many people are fearful of spiders, scorpions, and ticks, oribatid mites are not a concern for the health of humans and are actually beneficial, because they help with soil formation and with returning nutrients to the environment. Oribatid mites are also called beetle mites or armored mites because they typically have hard bodies (like beetles) to protect them from being eaten (Figures 1B,D). They are also sometimes called moss mites because they are abundant within mosses, a type of plant that grows close to the soil surface.

\section{WHAT DO ORIBATID MITES LOOK LIKE?}

Most adult oribatid mites are brown, but species range in color from nearly white, to yellow, to reddish-brown (Figures 1A, 2D), to almost black. Males and females look very similar in most species, but the young mites rarely look like the adult mites (Figures $1 \mathrm{E}-\mathrm{H}$ ). The females lay eggs and when the eggs hatch, the young mites (larvae) grow through three more stages before becoming adults. At each stage, they shed their outer body covering, called the exoskeleton, as their bodies get bigger. Some oribatid mites carry this old exoskeleton around on their backs as a form of camouflage to protect them from predator mites. Predator mites can eat some oribatid mites. Oribatid mites are mostly oval shaped, but some are very round like a ball when they curl their legs up into their bodies (Figure 1B). All oribatid mites have heads that are attached to the rest of their bodies and eight legs that attach in the middle region of their bodies. Most oribatid mites have tiny holes in their armpits that allow them to breathe; they do not have noses like we do. However, their legs have hairs to help them feel, taste, and even smell (Figures 1C,D, 2C). Their legs also have claws on the tips, similar to human nails (Figure 1D). Most oribatid mites do 
Figure 2

Diversity of oribatid mites, with their scientific names (A) Melanozetes crossleyi; (B) Hydrozetes sp. with an arrow pointing to the lenticulus, the structure that allows this oribatid mite to perceive light;

(C) Collohmannia johnstoni; (D) Cersella sp.; (E)

Nehypochthonius porosus and (F) juvenile Eupterotegeaus.

\section{LENTICULUS}

The structure that allows oribatid mites to perceive light since they do not have real eyes.

\section{CHELICERAE}

Mouthparts present in arachnids like spiders, scorpions, ticks and also oribatid mites.
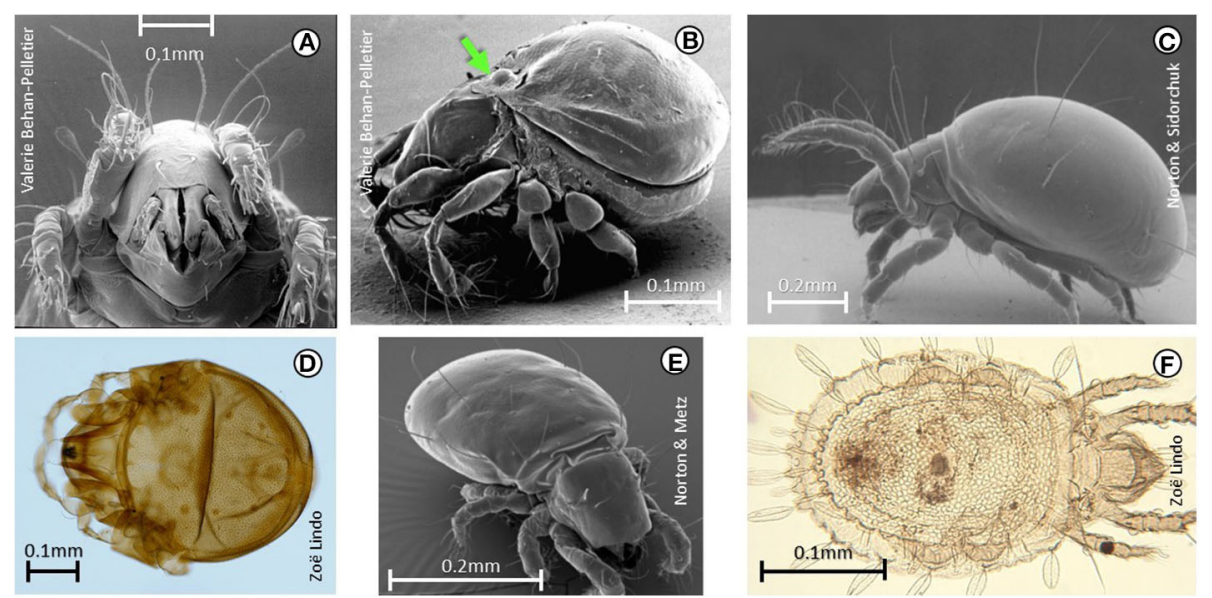

Figure 2

not have real eyes, but they have structures that can perceive light, for example, a structure called the lenticulus, seen in Figure 2B. They also do not have real teeth, but instead have tooth-like structures to help them feed (Figure 1D), called chelicerae.

Oribatid mites are very small organisms. The majority are $<1 \mathrm{~mm}$ long (most $0.3-0.7 \mathrm{~mm}$ ), which is the diameter of two human hairs side-by-side, but some can be as large as a pencil tip. Because these organisms are so small, we need to use a hand lens or a microscope to observe them. Even though oribatid mites are tiny and might look fragile at first glance, they have existed for many million of years, even before dinosaurs [1]!

Tiny oribatid mites move around in soil on their eight legs, but because they are so small, they usually move only a few meters during their entire lifetime. However, other strategies help oribatid mites to get to distant places, too. Oribatid mites can hitchhike on other animals like birds, frogs, and mammals for example, and then move long distances. Another strategy is, because they are so light, they can be picked up in the wind and travel in the air! How cool!

\section{DEFENSIVE MECHANISMS}

Oribatid mites may live for one or more years (some species up to 5 years) in their natural habitats. Because it takes them a long time to become mature adults, they do not have many babies, and they must protect themselves from predators. To protect themselves, oribatid mites have developed many different defensive mechanisms. These protective mechanisms include: hairs that raise (like a frightened cat) (Figure 1C), armored structures that cover their bodies like a tank (Figures 1D, 2A), bodies that roll into a protective ball (Figure $1 \mathrm{~B})$, or camouflage obtained by covering themselves in soil, their exoskeletons, or other debris. Many oribatid mites also possess 
Figure 3

Oribatid mites are

found in many different environments.

(A) Forest (Schwangau, Germany); (B) wetland (Massachusetts, U.S.);

(C) desert (Arizona,

U.S.); (D) treetop

(Vancouver island,

Canada); (E) edge of

the ocean (Espírito

Santo, Brazil); and (F)

edge of a lake

(Ásólfsskáli, Iceland)

NUTRIENT CYCLING

The movement of nutrients between living things and the earth, including the atmosphere, rivers, and soils. Oribatid mites help recycle nutrients in soils.

\section{DECOMPOSITION}

The break-down of dead plants and animals by fungi and bacteria, facilitated by oribatid mites and other soil animals.

\section{MESOFAUNA}

This term refers to intermediate-sized animals in soils. Their size ranges from 0.1 to $2 \mathrm{~mm}$.
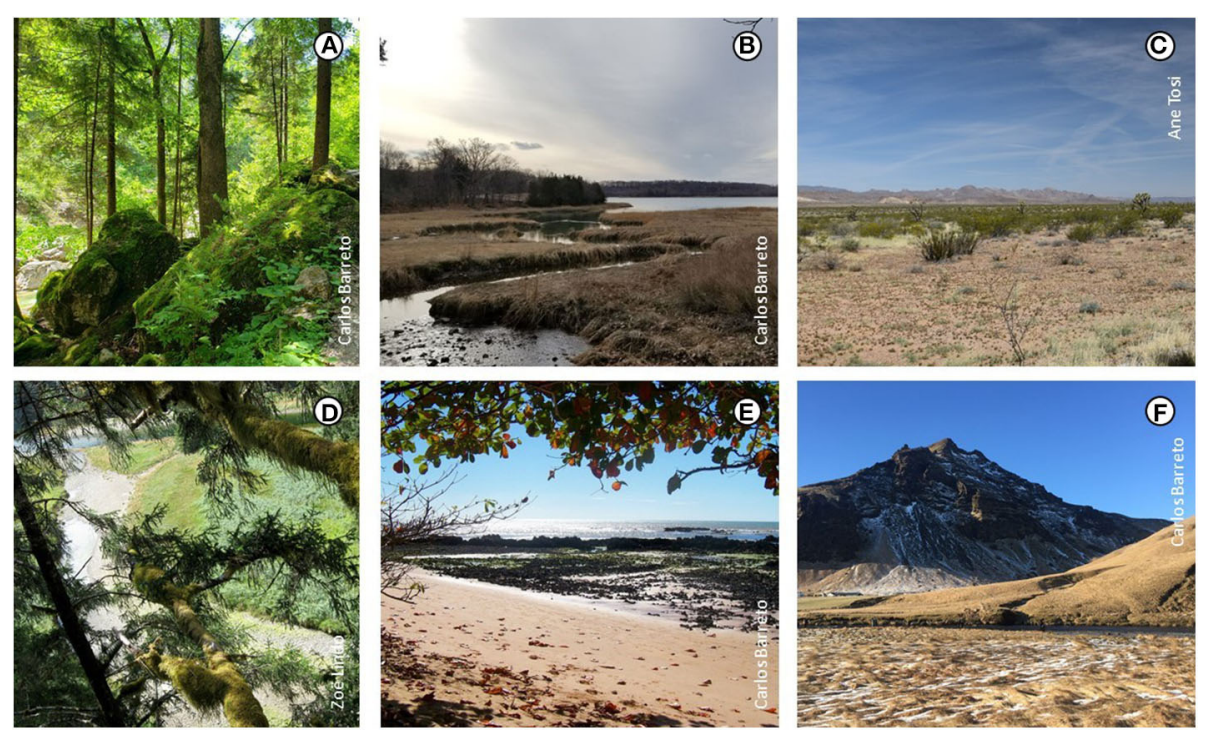

Figure 3

specialized defensive glands that can release unpleasant chemicals when they are attacked by their predators.

\section{WHY ARE ORIBATID MITES IMPORTANT?}

A typical diet for oribatid mites consists of different types of fungi and bacteria. Because of what they eat, oribatid mites are important for ecosystem services like nutrient cycling. The mites chew dead leaves, which breaks the leaves down into smaller pieces that fungi and bacteria can further decompose. When the oribatids then eat the fungi and bacteria, the nutrients from the leaves are returned to the soil after they are discharged in oribatid feces. Oribatid mites are considered part of the soil food web, helping with processes like decomposition that are necessary for soil formation.

\section{WHERE DO ORIBATID MITES LIVE?}

Oribatid mites have been found all over the world, from forests to deserts, and along the shores of lakes and oceans in all countries (Figure 3). They live mostly in soils, where they usually are the most abundant and diverse group of small soil animals called mesofauna [2]. But they can also live in other habitats, like on the bark and trunks of trees, in mosses, and on other plant leaf surfaces. Oribatid mites are also found at the top of the tallest trees, as well as in some aquatic environments. They are almost everywhere!

While there are over 10,000 species of oribatid mites known, we have good reasons to believe that there are many, many more species of oribatids that have not been discovered yet. The number of species of oribatid mites found in any location varies, depending on a number 


\section{EXTRACTOR}

Tool used to help separate oribatid mites and other soil animals from the surrounding soil. The lamp on top of it slightly heats the soil up and have the animals to leave the soil. of factors including the type of plants in the location, the climate, the amount of moisture in the soil, the $\mathrm{pH}$ of the soil, the concentration of soil nutrients, and the levels of soil pollution. Different species of oribatids prefer different conditions; for example, some prefer soil with lots of nutrients while others prefer low-nutrient soil. Depending on the environment, oribatid mites can reach impressive numbers - up to 500,000 individuals per $\mathrm{m}^{2}$ in forest soils [3]! This is equivalent to 4000 mites in a handful of soil!

\section{HOW CAN I FIND ORIBATID MITES?}

If you want to observe oribatid mites and other soil organisms, you will need an extractor to help separate the oribatid mites from the surrounding soil, and a microscope or hand lens. In Box 1, we describe the materials you will need to build your own soil oribatid mite extractor. You will need adult supervision for this, but it is easy. Once you have your soil organisms separated from the soil, use a hand lens to see how different they all are. If you have access to a microscope, then even better!

Go to your backyard, or to a public park. Oribatid mites can be found in cities too. You will need to collect two to three handfuls of soil, leaf litter, or mosses (dig up to $10 \mathrm{~cm}$ deep) for your extractor. You will also need to be a little patient; it will likely take a minimum of 3 days to extract the oribatids from your soil sample. Okay, time to build the extractor!

Last, if you are interested in soils and who lives in them, there are many other activities that can be found in Chapter VII of the Global Biodiversity Atlas [4]. Links for books, games, videos, and more are all available! Have fun!

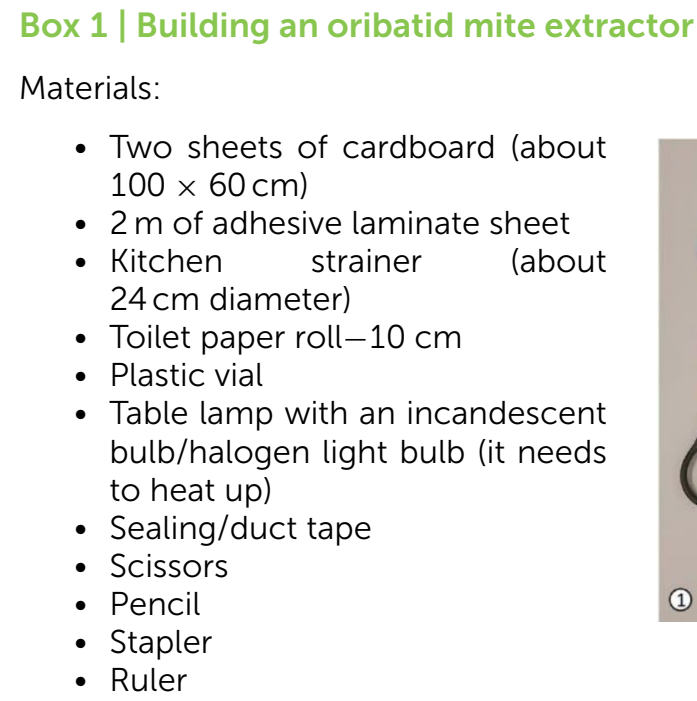

- Two sheets of cardboard (about $100 \times 60 \mathrm{~cm})$

- $2 \mathrm{~m}$ of adhesive laminate sheet

- Kitchen strainer (about $24 \mathrm{~cm}$ diameter)

- Toilet paper roll-10 cm

- Plastic vial

- Table lamp with an incandescent bulb/halogen light bulb (it needs to heat up)

- Sealing/duct tape

- Scissors

- Pencil

- Stapler

- Ruler

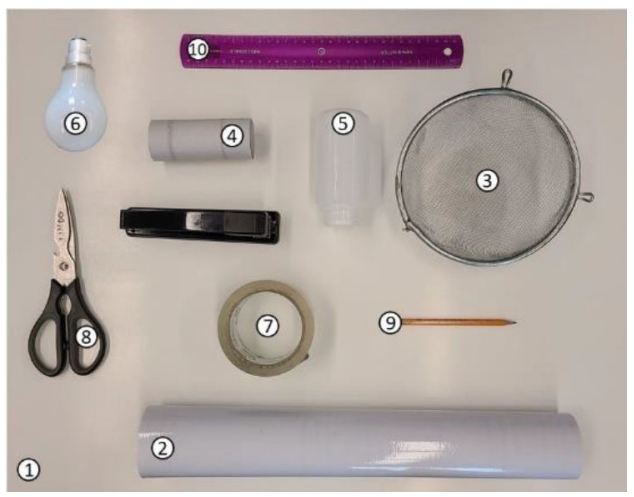

(Continued) 


\section{Box 1 | Continued}

Methods:

- Draw a semi-circle on one of the cardboard sheets. The semi-circle should have a radius of $25 \mathrm{~cm}$. Cut it out using scissors (A). Cover both sides with the adhesive laminate sheet and cut a semi-circle in the middle.

- Fold it to form a funnel and staple it using the stapler (B). The funnel must have an opening at the bottom-this is where the oribatid mites and other soil animals will pass through.

- Attach the toilet paper roll to the bottom of the funnel using the tape (C).

- Cover the other piece of cardboard with the laminate sheet (D). Use it to create a 25 $\mathrm{cm}$-long cylinder. Close it with staples. This will be attached later onto the big opening (top) of the funnel.

- Place the kitchen strainer on top of the funnel/bottom end of the cylinder (E).

- Use the tape to secure the cylinder to the funnel (with the strainer in between) (F).

- Put the soil sample on the strainer from the top of the cylinder.

- Put the plastic vial at the bottom end of the extractor.

- Put the table lamp near the top opening of the cylinder and turn the light on. This will encourage the oribatids to leave the soil (G).
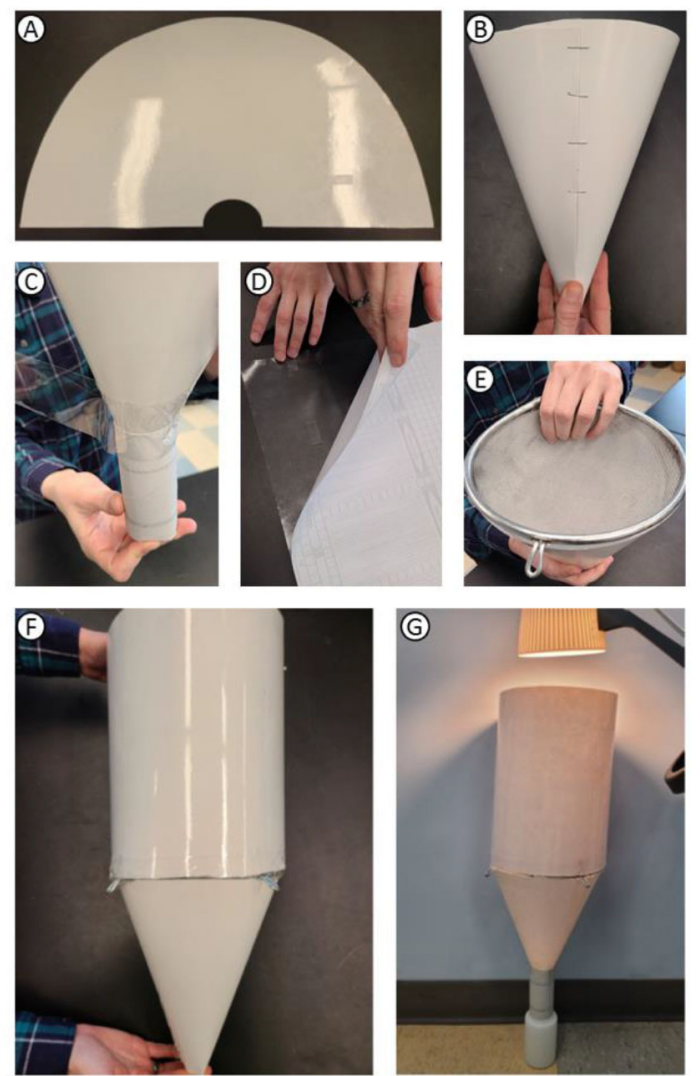

\section{AUTHORS CONTRIBUTIONS}

CB and ZL wrote the manuscript. CB created the figures and made the manual for creating the fauna extractor.

\section{ACKNOWLEDGMENTS}

We were very grateful to Dr. Roy Norton and Dr. Valerie Behan-Pelletier, our mentors in the field of oribatid mites, for the great suggestions. Special thanks to Caitlyn Lyons, who helped us with making the language appropriate for children, and to our great young reviewers 
and their Science mentors. We thank Marilia Paulon for the help building the extractor. We also thank Dr. Malte Jochum for the invite to be part of this great initiative.

\section{REFERENCES}

1. Labandeira, C. C., Phillips, T. L., and Norton, R. A. 1997. Oribatid mites and the decomposition of plant tissues in paleozoic coal-swamp forests. Palaios 12:319-53.

2. Behan-Pelletier, V. M., and Bissett, B. 1992. Biodiversity of Nearctic soil arthropods. Can. Biodivers. 2:5-14.

3. Coleman, D., Crossley, D., and Hendrix, P. F. 2004. Fundamentals of Soil Ecology, 2nd Edn. Amsterdam: Elsevier Academic Press, 1-386.

4. Orgiazzi, A., Bardgett, R. D., Barrios, E., Behan-Pelletier, V., Briones, M. J. I., Chotte, J. L., et al. (Eds.). 2016. Global Soil Biodiversity Atlas. Luxembourg: European Commission, Publications Office of the European Union.

SUBMITTED: 24 March 2020; ACCEPTED: 03 September 2020;

PUBLISHED ONLINE: 03 November 2020.

EDITED BY: Malte Jochum, German Centre for Integrative Biodiversity Research (iDiv), Germany

CITATION: Barreto C and Lindo Z (2020) Armored Mites, Beetle Mites, or Moss Mites: The Fantastic World of Oribatida. Front. Young Minds 8:545263. doi: 10. 3389/frym.2020.545263

CONFLICT OF INTEREST: The authors declare that the research was conducted in the absence of any commercial or financial relationships that could be construed as a potential conflict of interest.

COPYRIGHT @ 2020 Barreto and Lindo. This is an open-access article distributed under the terms of the Creative Commons Attribution License (CC BY). The use, distribution or reproduction in other forums is permitted, provided the original author(s) and the copyright owner(s) are credited and that the original publication in this journal is cited, in accordance with accepted academic practice. No use, distribution or reproduction is permitted which does not comply with these terms.

\section{YOUNG REVIEWERS}

\section{ISABEL, AGE: 10}

$\mathrm{Hi}$, I am Isabel and I am from Portugal. I am 10 and I like reading, writing, and music. I have three cats and I like to learn about history. I have no idea of what I want to be when I grow up. I really like vegetables (and fruit). 


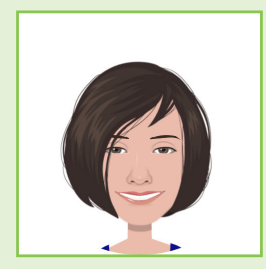

\section{MARGARIDA, AGE: 12}

My name is Margarida, I am 12 years old and I like reading, climbing, and writing. I love science, especially anything about black holes and I have absolutely no idea what I want to do when I grow up. I also really like biology.

\section{AUTHORS}
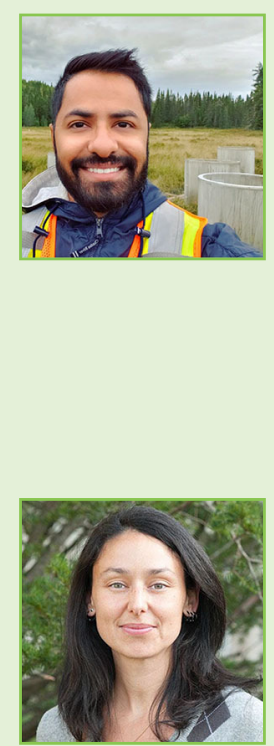

\section{CARLOS BARRETO}

At a very young age Carlos realized that he liked animals, maybe too much. In school, science was always his favorite discipline, all the way through to high school. That is when he decided that he wanted to do something that involved science and animals. He tried to be a vet; it did not work out. No regrets. So, he became an Ecologist a few years later, and since then, he has been working with little animals (mostly insects and mites) in tropical forests, iron ore and limestone caves, boreal forests, urban fields, and peatlands on three continents: South America, North America, and Europe. * ${ }^{*}$ barreto@uwo.ca; ${ }^{\dagger}$ orcid.org/0000-0003-2859-021X

\section{ZOË LINDO}

Dr. Zoë Lindo is an expert on soil biodiversity and ecosystem function. She has worked extensively in Canadian forests, including the mixed-wood boreal of Alberta, the subarctic taiga of Quebec, the coastal temperate rainforest of British Columbia, and the black spruce/peatlands of Ontario. "The overall focus of my research aims to mitigate biodiversity loss in association with human-induced environmental change and maintain ecosystem functioning in Canadian forest and soil ecosystems. I describe myself as a biodiversity scientist to encompass the breadth of my research in the areas of community ecology, soil ecology, and taxonomy." "orcid.org/0000-0001-9942-7204 